напряжение и ответ, т. е. силу реакции на «внешние» негативные эмоциональные стимулы. Полученные данные свидетельствуют о том, что электродермальные потенциалы могут служить объективными критериями формирования эмоционального выгорания.

Ключевые слова: статические электрические потенциалы (СТЭП), биологически активные зоны кожи человека (БАЗ), уровень эмоционального выгорания.

Tukaiev Sergii, Fedorchuk Svitlana, Chikina Liudmyla, Gerasko Taisia, Zy ma Igor, Zaichenko Aleksandr, Havrylets Yurii, Rizun Volodymyr, Bogdanov Volodymyr, Gorgo Yurii. The Skin Potential Level of Facial Biologically Active Zones as Indicators of the Level of Emotional Burnout in Students.

Introduction. Emotional burnout syndrome sees as a reaction to stress in interpersonal communication in the form of full or partial shutdown of emotions. V. Boyko dynamic model of burnout that was used as basis of this study classified in 3 stages in accordance with the mechanism of stress. There exist 3 phases: Anxiety Tension, Resistance, and Exhaustion. Strengthening of stressful factors in everyday life triggers the formation of emotional burnout (Anxiety Tension stage). The respondents with «Resistance» stage begin to economize emotion and characterize by emotional and moral disorientation. The central nervous activity reduction and the fall in energy tone are evident in the «Exhaustion» stage. Inadequate reactions to the different stimulus are associated with the hyperreactivity of the nervous system. The skin potential level (SPL) of facial biologically active zones (BAZs) reflects the level of background activation of brain structures and the level of mental stress. That is why skin potential level reflects the formation of emotional burnout.

Purpose. The aim of the study was to detect the changes of SPL in symmetric biologically active zones of face skin (frontal, superciliary, paranasal, temporal, periotic and postaural) depending on the level of emotional burnout.

Methods. 31 healthy volunteers (women and men) - first-third year students $\left(\mathrm{M}_{\mathrm{age}}=19.07, \mathrm{SD}=1.91\right.$ years, from 17 to 23 years) were recruited from the Taras Shevchenko National University of Kyiv, Educational and Scientific Centre «Institute of Biology and Medicine» and Faculty of Psychology, and participated for course credit during preexam period. Skin potential level was recorded via nonpolarizable silver electrodes from the symmetric biologically active zones of face skin (frontal, superciliary, paranasal, temporal, periotic and postaural) with the palm as a reference area. To determine the stages of burnout we used the Boyko «Syndrome of emotional burnout» test adapted for students by Tukaiev and Vasheka. The value of each of Burnout stages was measured on a scale from 0 to 120 points: 0 to 36 points - the stage was not formed, 37 to 60 points - the stage was under development, 61 to 120 points - the stage was formed. The Speerman rank test was carried out for the correlation analysis.

Results. Inverse correlation was found between the formation of emotional burnout and the skin potential level in right periotic BAZ (parotid BAZ) $(\mathrm{r}=-.43, \mathrm{p}<.05)$. We found correlation between the development of the Resistance stage of burnout and background SPL in the right and left frontal BAZ (respectively $r=-.44$ and $r=-.47, p<.05$ ) and SPL in the left frontal BAZ after the exposure of negative frames of documentaries $(r=-.50, p<.01)$.

Conclusion. Our data indicates that the formation of burnout reduced the prestarting initial emotional tension and response strength to «external» negative emotional stimuli. It indicates that electrodermal potentials can serve as objective criteria of formation of emotional burnout.

Key words: skin potential level (SPL), biologically active zones (BAZs), emotional burnout.

Стаття надійшла до редколегії 24.09.2016 р.

УДК $612.82 / .83 ; 612.821$

\author{
Артем Охрей, \\ Тетяна Куценко, \\ Микола Макарчук
}

\section{Моторна асиметрія в музикантів і немузикантів під час оцінки оперативної пам'яті й уваги}

Оцінено швидкість та ефективність виконання тесту Струпа й тесту з оцінки оперативної пам'яті в музикантів і немузикантів. Установлено, що музиканти та немузиканти однаково ефективно виконують прямий і зворотний тести Струпа, а також не різняться за показниками розвитку оперативної пам'яті, проте під час виконання обох тестових завдань у музикантів моторна асиметрія реакцій правої й лівої рук $є$ меншою.

Ключові слова: моторна асиметрія, оперативна пам'ять, прямий і зворотний тести Струпа, музиканти, немузиканти.

(C) Охрей А., Куцеенко Т. Макарчук М., 2016 
Постановка наукової проблеми та їі значення. Відомо, що тривалі й регулярні заняття музикою приводять до морфофункціональних перебудов головного мозку людини. Зміни, які при цьому виникають, мають адаптивний характер і спрямовані на забезпечення кращого виконання музичного твору чи досконалішої гри на музичному інструменті. Проте в науковій літературі часто постає питання щодо того, чи обмежується вплив занять музикою лише покращенням тих функцій, які безпосередньо стосуються iї виконання (моторика, аудіомоторна координація та ін.), чи він може «поширюватися» й на інші системи мозку? У цьому контексті найбільший інтерес викликає 3' ясування впливу занять музикою на когнітивні процеси людини (пам'ять, увагу тощо) у зв'язку 3 потенційною можливістю застосування музикотерапевтичних прийомів у медичній, реабілітаційній і педагогічній практиці [1]. Зокрема, установлено, що музиканти, порівняно з обстежуваними без вокально-інструментального досвіду, показують кращі результати у візуально-просторових [2], математичних тестах [3; 4; 5], завданнях на вербальну пам'ять [6] і навіть вищий IQ [7; 8]. Проте питання «підвищення» когнітивних можливостей на фоні регулярних занять музикою лишається відкритим, як нез'ясованими є й нейрофізіологічні механізми, що лежать в його основі. Однак George та Coch (2011) запропонували припущення, що заняття музикою приводять до покращення роботи оперативної пам'яті людини (ОП) і виконавчих функцій мозку [9]. Наведемо відомості про позитивні впливи занять музикою на ефективність функціонування компонентів ОП: візуальнопросторового блоку [9], артикуляційної петлі [9; 10; 11], центрального процесора [9; 11; 12]. 3 іншого боку, між дослідженнями існують і суперечності. Зокрема, Lee et al. (2007) наводить дані про ефективніше функціонування артикуляційної петлі в дорослих музикантів, порівняно 3 немузикантами, але не знаходить відмінностей у роботі центрального процесора й візуально-просторового блоку [10]. Strait et al. (2010) також не виявили значущої різниці між музикантами та немузикантами в завданні із залученням центрального процесора [13].

Іншим можливим механізмом, що лежить в основі потенційного покращення когнітивних функцій у музикантів, може бути більш тісна й тренована міжпівкульна кооперація, адже виконання музичного твору потребує комплексної взаємодії багатьох систем мозку як у межах, так і між півкулями. До того ж відомо, що під час певних когнітивних завдань півкулі працюють узгоджено, чим досягається вища ефективність виконання завдання [14], а регулярні заняття музикою як такі приводять до зменшення функціональної асиметрії в музикантів [15]. Навіть самі по собі компоненти ОП мають різну функціональну латералізацію й спроможні до кооперації [16; 17].

Ураховуючи описану вище проблематику, у цьому дослідженні ми вирішили продовжити та поглибити з'ясування впливу занять музикою на когнітивні функції людини. Ми припускаємо, що музиканти, порівняно з немузикантами, мають більш тісну міжпівкульну взаємодію й меншу функціональну асиметрію під час виконання когнітивних завдань. У цьому дослідженні застосовано психофізіологічні комп'ютеризовані тести з оцінки розвитку ОП та системи уваги. Зазначимо, що дизайн цих тестів дає змогу простежувати функціональну асиметрію, яка виникає під час їх проходження, оскільки відповіді надаються обома руками.

Мета дослідження - 3'ясування моторної асиметрії під час виконання тестів 3 оцінки ОП та уваги музикантами й немузикантами.

Матеріали й методи дослідження. У дослідженні брали участь 66 обстежуваних - студенти обох статей віком від 17 до 23 років. До група музикантів (n=28) увійшли студенти Київської національної музичної академії ім. П. Чайковського, котрі мали 10-14 років музичного досвіду (музична школа, музичне училище, вищий навчальний заклад). До групи немузикантів (n=38) належали студенти ННЦ «Інститут біології» Київського національного університету імені Тараса Шевченка без будь-якого попередньої досвіду гри чи співу. Усі обстежувані були праворукими, не мали психічних чи неврологічних порушень.

Для оцінки ОП і системи уваги використано авторське програмне забезпечення, розроблене на кафедрі фізіології людини і тварин [18].

Тестування ОП складалося 3 трьох субтестів. У першому оцінювали пам'ять на візуально представлені приголосні літери. Для цього обстежуваний розташовувався перед екраном комп'ютера на відстані 50 см від нього. На екран комп'ютерного монітора подавали множину (набір) із початковою кількістю дві літери. Кількість літер після 10 повторень кожної множини зростала на одиницю (фінальна кількість літер у наборі - 7; літери комбінувалися випадковим чином). Час 
експозиції кожної множини становив 1,5 с, після чого вона згасала й через 1 с з’являлася тестова літера. Якщо вона була в попередній множині, обстежуваний повинен був натиснути правою рукою клавішу «/» на клавіатурі комп'ютера (відповідь - «так»), якщо ж іiі там не було - лівою рукою клавішу «Z» (відповідь - «ні»).

Другий і третій субтести організовані за аналогічною схемою. У другому субтесті оцінювали оперативну пам’ять на візуально представлені цифри, у третьому - на геометричні фігури.

Оцінку роботи системи уваги проводили за допомогою тесту Струпа [19]. Ми використовували комп'ютеризовану модифікацію тесту, розроблену на кафедрі фізіології людини і тварин [20]. Суть цього тесту - у поданні обстежуваним слів, що означають назви кольорів (наприклад «ЗЕЛЕНИЙ»). Вони можуть бути висвітлені як «своїм» кольором (конгруентні подразники), так і мати інше забарвлення, яке не збігається зі значенням пред'явленого слова (неконгруентний подразник). Неконгруентні подразники аналізуються повільніше, ніж конгруентні, а обстежувані при цьому допускають більше помилок. Це явище називається ефектом Струпа (ефектом інтерференціï). Із психофізіологічного погляду, ефект Струпа можна пояснити конкуренцією двох потоків інформації (вербальної й інформації про колір), які призводять до появи конфліктуючих відповідей [21]. Це активує передню поясну звивину, що залучає ресурси дорзолатеральної префронтальної кори (передня система уваги). Чим ефективніша активація фронтальних нейронних мереж, тим сильнішим стає когнітивний контроль над виконанням завданням, що приводить до зменшення кількості помилкових відповідей [22].

Для тестування ефекту Струпа в центрі монітора комп'ютера послідовно у псевдовипадковому порядку з'являлися слова «ЗЕЛЕНЫЙ» і «КРАСНЫЙ», написані зеленим або червоним кольором, незалежно від їх значення. Усього пред'явлено 240 слів. Застосовували прямий та зворотний тести Струпа. У прямому тесті релевантною інформацією $\epsilon$ колір, а семантичне значення слова ігнорується. Обстежувані повинні натискати правою рукою клавішу «Р» (англійська розкладка) на слова, висвітлені червоним кольором, та клавішу «Q» лівою рукою на зелені слова. У зворотному тесті Струпа релевантною інформацією є семантичне значення слова, а інформація про колір ігнорується. Обстежувані повинні натискати правою рукою клавішу «Р» на слово «КРАСНЫЙ» і клавішу «Q» лівою рукою на слово «ЗЕЛЕНЫЙ».

У ході всіх тестів реєстрували латентний період реакції обстежуваних (ЛП) із точністю до 10 мс, а також загальну кількість допущених помилок як показник успішності виконання того чи іншого тесту або субтесту.

Статистичний аналіз даних проводили за допомогою пакета STATISTICA (StatSoft, USA, 2001). Нормальність розподілів перевіряли за тестом Шапіро-Вілка. Оскільки більшість даних мала розподіл, відмінний від нормального (p<0,05), то для опису випадкового розподілу використовували медіану (Ме), а також верхній і нижній квартилі ([25; 75]). Для порівняння двох незалежних вибірок застосовували критерій Манна-Вітні, залежних - критерій Вілкоксона. Критичний рівень значущості (р) під час перевірки статистичних гіпотез уважали рівним 0,05 i на графіках позначали як «*» $(\mathrm{p}<0,01$ позначали «**», $\mathrm{p}<0,001-\ll * * * »)$.

Виклад основного матеріалу й обгрунтування отриманих результатів дослідження. Загалом, за загальною кількістю помилок не виявлено відмінностей між музикантами та немузикантами протягом усіх тестів (див. табл. 1). Це може засвідчувати, що всі обстежувані, незалежно від наявності музичного досвіду, мають однакову успішність виконання завдань.

Таблиия 1

Загальна кількість помилкових реакцій музикантів і немузикантів під час тестування ОП і системи уваги

\begin{tabular}{|l|l|l|}
\hline \multicolumn{1}{|c|}{ Назва тесту } & \multicolumn{1}{|c|}{ Немузиканти } & \multicolumn{1}{|c|}{ Музиканти } \\
\hline ОП (літери) & $14[12 ; 15]$ & $13[12 ; 14]$ \\
\hline ОП (цифри) & $14[13 ; 15]$ & $14[12 ; 16]$ \\
\hline ОП (фігури) & $19,5[17 ; 22]$ & $20[17 ; 22,5]$ \\
\hline Прямий тест Струпа & $3[1 ; 6]$ & $2[1 ; 6]$ \\
\hline Зворотний тест Струпа & $2[1 ; 6]$ & $3[1 ; 6]$ \\
\hline
\end{tabular}


За даними аналізу результатів тестування ОП з'ясовано, що ліва рука допускала більше помилок (табл. 2) і мала довший ЛП реакції, ніж права, протягом усіх субтестів (табл. 3). Така асиметрія проявлялася в обох групах, проте була більш вираженою в групі немузикантів.

Таблиия 2

Кількість помилкових реакцій правої й лівої рук у субтестах з оцінки розвитку оперативної пам'яті в музикантів і немузикантів

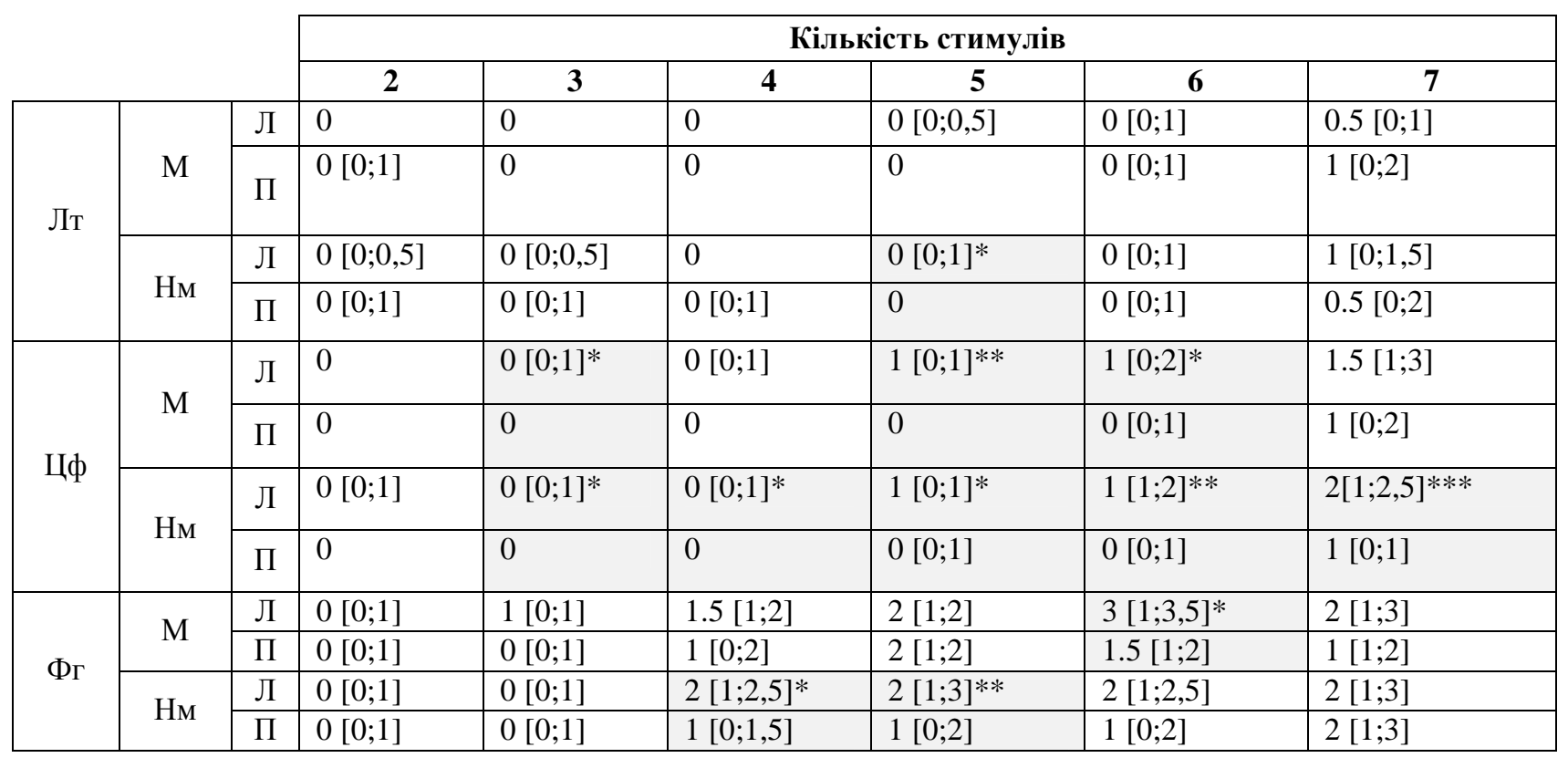

Умовні позначення. Лт - субтест із літерами, Цф - субтест із ичифрами, Фг - субтест з геометричними фігурами; М - музиканти, Нм - немузиканти; Л - ліва рука, П - права рука. Статистично значущі відмінності позначені між кількістю помилок, допущених лівою й правою руками в межах кожної групи.

Таблиия 3

Латентні періоди реакцій правої й лівої рук у субттестах з оцінки розвитку оперативної пам'яті в музикантів і немузикантів

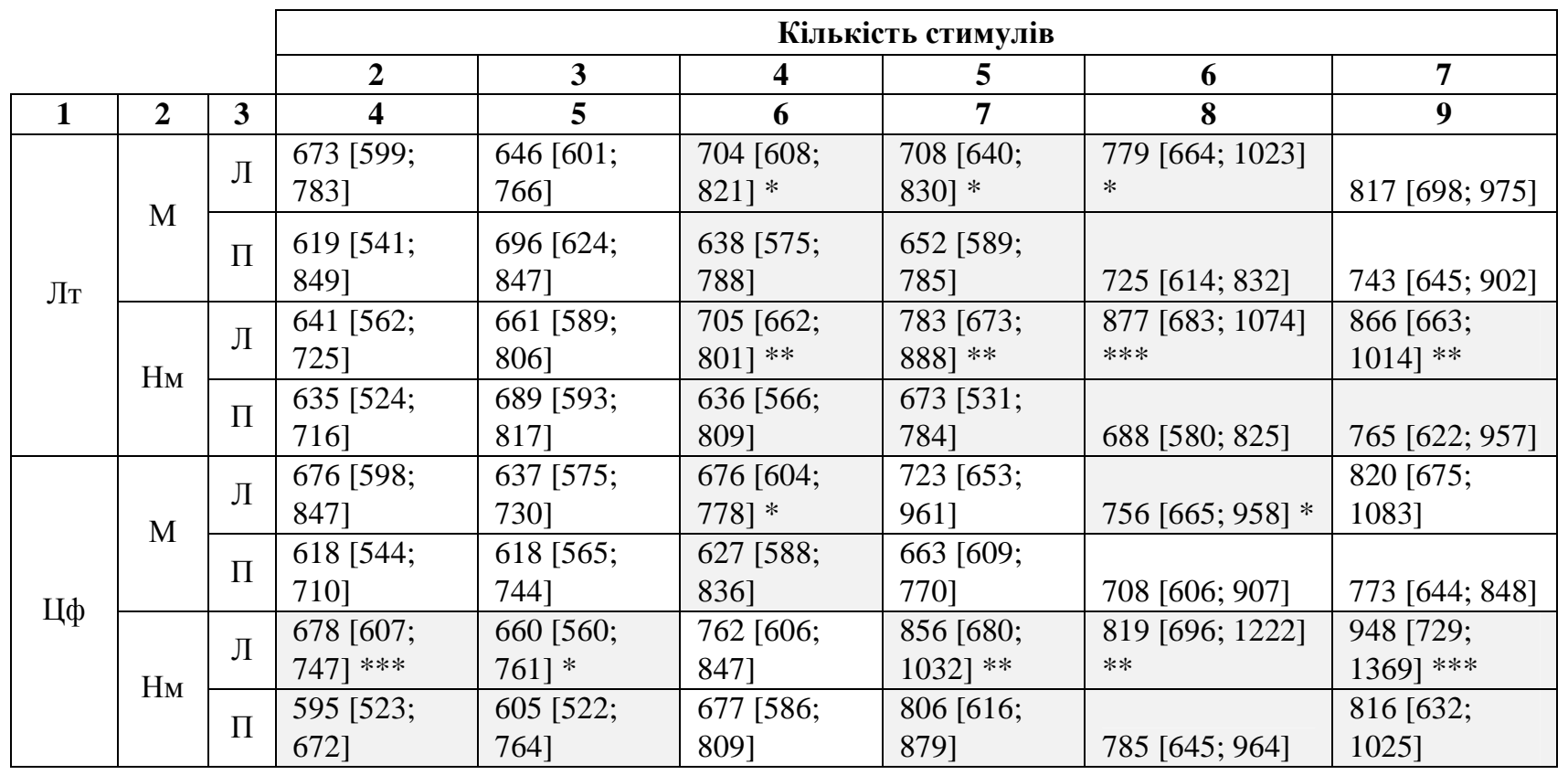


РОЗДІЛ IV. Фізіологія людини і тварин. 12, 2016

Закінчення таблиці 3

\begin{tabular}{|c|c|c|c|c|c|c|c|c|}
\hline 1 & 2 & 3 & 4 & 5 & 6 & 7 & 8 & 9 \\
\hline \multirow{4}{*}{$\Phi_{\Gamma}$} & \multirow[t]{2}{*}{ Мз } & Л & $\begin{array}{l}788 \text { [673; } \\
936]\end{array}$ & $\begin{array}{l}850[700 ; \\
1023]\end{array}$ & $\begin{array}{l}795[673 ; \\
990]\end{array}$ & $\begin{array}{l}848 \text { [798; } \\
1015]\end{array}$ & $847[715 ; 1045]$ & $\begin{array}{l}794[616 ; \\
1120]\end{array}$ \\
\hline & & $\Pi$ & $\begin{array}{l}674 \text { [608; } \\
880]\end{array}$ & $\begin{array}{l}707[600 ; \\
820] * * *\end{array}$ & $\begin{array}{l}720[580 ; \\
890]\end{array}$ & $\begin{array}{l}685[620 ; \\
820] * * *\end{array}$ & $\begin{array}{l}697[623 ; 930] \\
* *\end{array}$ & $\begin{array}{l}714[548 ; 990] \\
*\end{array}$ \\
\hline & \multirow{2}{*}{ Нм } & Л & $\begin{array}{l}768[642 ; \\
926] * *\end{array}$ & $\begin{array}{l}768[637 ; \\
988]\end{array}$ & $\begin{array}{l}844[693 ; \\
1026] *\end{array}$ & $\begin{array}{l}863[715 ; \\
1195] *\end{array}$ & $\begin{array}{l}840[710 ; 1113] \\
*\end{array}$ & $\begin{array}{l}870[760 \\
1135] * * \\
\end{array}$ \\
\hline & & $\Pi$ & $\begin{array}{l}694 \text { [550; } \\
852]\end{array}$ & $\begin{array}{l}782 \text { [614; } \\
888]\end{array}$ & $\begin{array}{l}690 \text { [627; } \\
880]\end{array}$ & $\begin{array}{l}783[633 ; \\
1010]\end{array}$ & $741[585 ; 998]$ & 770 [608; 908] \\
\hline
\end{tabular}

Умовні позначення відповідають таким, як на табл. 1. Статистично значущі відмінності позначені між латентними періодами реакиій лівої й правої рук у межах кожної групи.

За результатами прямого тесту Струпа виявлено, що як музиканти, так і немузиканти однаково демонстрували виражений ефект Струпа для обох рук (рис. 1).

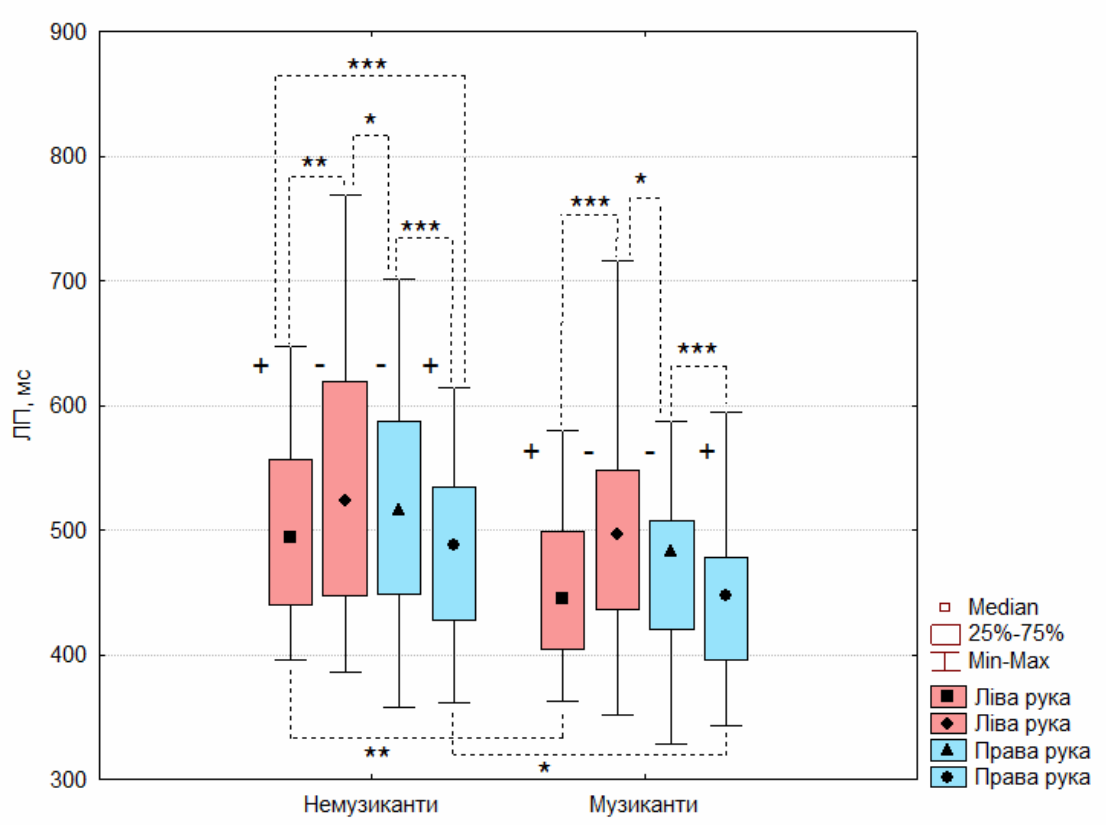

Рис. 1. Латентні періоди реакцій правої й лівої рук музикантів та немузикантів під час проходження прямого тесту Струпа:

«+»-конгруентний стимул, «-»-неконгруентний стимул

Крім того, у межах групи немузикантів проявлялася моторна асиметрія, подібна до тієї, що під час тестування ОП: ЛП-реакції правої руки були коротшими, ніж лівої. Ця закономірність проявлялася під час подачі як конгруентних, так і неконгруентних стимулів. Відзначимо, що музиканти також відповідали швидше правою рукою, ніж лівою, але лише у випадку подачі неконгруентних стимулів, тобто коли завдання ставало складнішим. До того ж у випадку подання конгруентних стимулів музиканти демонстрували коротші ЛП реакцій обох рук, порівняно з немузикантами (див. рис. 1).

Результати зворотного тесту Струпа також указують на прояв ефекту інтерференції в представників обох груп, однак якщо в групі немузикантів ефект Струпа виявлено як для правої, так i для лівої руки, то в групі музикантів - лише для лівої (рис. 2).

Зазначимо, що за результатами зворотного тесту Струпа не виявлено моторної асиметрії в межах груп, а також міжгрупових відмінностей ЛП реакцій обох рук.

Узагальнюючи результати дослідження, можна стверджувати, що музиканти та немузиканти мають однакову успішність виконання тестів на ОП, критерієм якої була загальна кількість помилок. Імовірно, ОП як одна з базових характеристик забезпечення вищої нервової діяльності, яка $\epsilon$ критично важливою для виживання [23], не може відрізнятись у межах виду. Однак, як зазначено вище, 


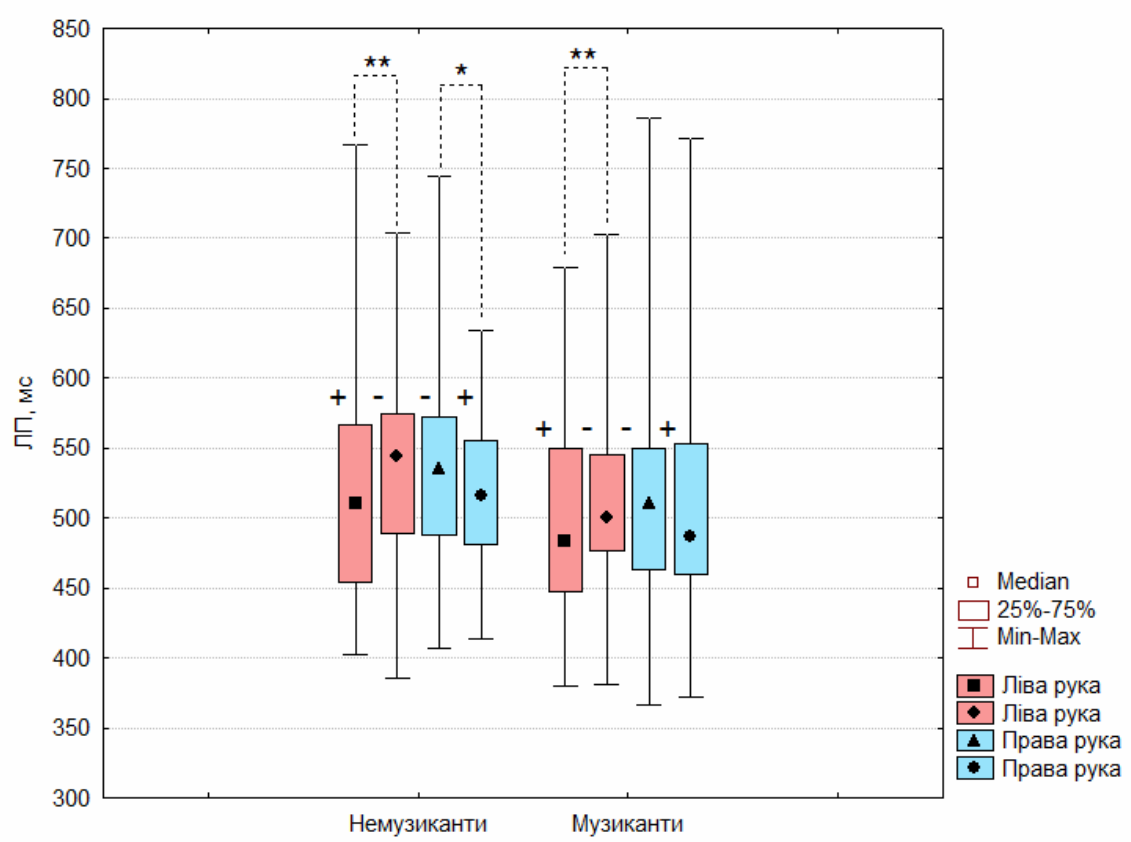

Рис. 2. Латентні періоди реакцій правої й лівої рук музикантів та немузикантів під час проходження зворотного тесту Струпа:

«+»- конгруентний стимул, «-»-неконгруентний стимул

деякі дослідники все ж наводять відомості про те, що музиканти досягають кращих показників у тестах на ОП, ніж немузиканти $[9 ; 10 ; 11 ; 12]$. На нашу думку, подібне розходження в результатах можна пояснити різними методичними підходами до тестування, адже в наведених вище дослідженнях використано парадигму Стернберга [24], згідно з якою стимули обстежувані отримують для запам'ятовування послідовно, а надання відповіді очікується в кінці, після завершення пред'явлення серії подразників. У нашому ж дослідженні застосовано парадигму Сперлінга [25], в основі якої метод одночасного пред'явлення стимулів. Після короткої експозиції множини стимулів (1,5 с) обстежувані повинні були одразу зреагувати на тестовий подразник. Це мінімізує можливість повторення інформації перед наданням відповіді, а також утворення асоціацій, які б могли привести до кращого утримання одиниць інформації в пам'яті протягом тесту.

За загальною кількістю помилок, допущених протягом виконання прямого й зворотного тестів Струпа, нами також не виявлено відмінностей між обстежуваними обох груп. Як музиканти, так і немузиканти однаково демонстрували виражений ефект інтерференції для правої й лівої рук протягом прямого тесту Струпа, що проявлявся у вигляді подовження ЛП реакцій на неконгруентні стимули. Імовірно, ці дані вказують на однакову ефективність роботи систему направленої уваги в представників обох груп. Однак під час зворотного тесту Струпа музиканти демонстрували ефект інтерференції лише для лівої руки, у той час як немузиканти - для обох рук. Імовірно, зміна типу релевантної інформації з невербальної на вербальну приводить до посилення когнітивного контролю лівої півкулі в музикантів.

За результатами тестування ОП виявлено, що ліва рука помиляється частіше, порівняно 3 правою (див. табл. 2), і має довші ЛП реакцій (див. табл. 3). Причому така закономірність більше виражена в групі немузикантів. На перший погляд, більш короткі ЛП ствердних реакцій правої руки, порівняно із заперечними відповідями лівої, можна пояснити припиненням пошуку в репрезентації множини стимулів в ОП, якщо тестовий подразник у ній знайшовся. Однак установлено, що навіть при зміні типу реагування на протилежний (права рука відповідає «ні», ліва - «так»), права рука все рівно демонструє більш швидкі моторні реакції [26]. Імовірно, поясненням подібної закономірності може бути лівопівкульна латералізація моторного контролю [27]. Згідно з Derakhshan (2010), команда на здійснення рухової реакції формується в домінантній (у 80 \% населення - у лівій) півкулі. Тому моторні реакції правої руки є швидшими, а лівої - повільнішими за рахунок транскалозальної 
затримки при перенесенні інформації. Ураховуючи ці дані, можна стверджувати, що менший прояв моторної асиметрії в музикантів під час тестування ОП пояснюється, імовірно, меншою транскалозальною затримкою й більш узгодженою роботою півкуль. Результати прямого тесту Струпа також указують на це, адже під час пред'явлення конгруентних стимулів музиканти взагалі не демонстрували моторної асиметрії, тоді як у групі немузикантів реакції правої руки були швидшими, ніж лівої (див. рис. 1). Водночас відповіді музикантів у цілому мали коротший ЛП, порівняно 3 немузикантами. Однак у випадку подання неконгруентних стимулів моторна асиметрія проявлялася в обох групах, що, можливо, пояснюється ускладненням завдання й необхідністю посилення когнітивного контролю лівої півкулі.

Загалом, результати нашого дослідження стосовно більш вираженої симетрії в роботі півкуль музикантів узгоджуються з даними інших авторів. Зокрема, установлено, що музиканти демонструють менш виражену функціональну асиметрію під час бісекційного тесту [28] та не мають міжпівкульних відмінностей у латентності компонента N1 під час реєстрації зорових викликаних потенціалів [29], у той час як у групі немузикантів компонент N1 3'являвся раніше в лівій півкулі. Крім того, у нашому попередньому дослідженні показано, що в музикантів відсутня міжпівкульна різниця в часі появи компонентів когнітивних викликаних потенціалів (N2, P3, N3), тоді як у немузикантів ці компоненти 3'являлися раніше в лівій півкулі [30].

Висновки та перспективи подальшого дослідження. Ефективність та результативність роботи системи уваги та оперативної пам'яті не відрізняється в музикантів та немузикантів. Однак музиканти демонструють більш виражену симетричність у роботі півкуль, порівняно з немузикантами, під час виконання когнітивних завдань із залученням оперативної пам'яті й системи спрямованої уваги.

\section{Джерела та література}

1. Панюшева Т. Д. Музыкальный мозг: обзор отечественных и зарубежных исследований / Т. Д. Панюшева // Асимметрия. - 2008. - Т. 2, № 2. - С. 41-54.

2. Patston L. Attention in musicians is more bilateral than in non-musicians / L. Patston, S. Hogg, L. Tippett // Laterality. - 2007. - V.12, № 3. - P. 262-272.

3. Gardiner M. Learning improved by arts training / M. Gardiner, A. Fox, F. Knowles [et al.] // Nature. - 1996. V. 381. - P. 284.

4. Cheek J. M. Music training and mathematics achievement / J. M. Cheek, L. R. Smith // Adolescence. - 1999. V. 34, № 136. - P. 759-761.

5. Graziano A. B. Enhanced learning of proportional math through music training and spatial-temporal training / A. B. Graziano, M. Peterson, G. L. Shaw // Neurological Research. - 1999. - V. 21, № 2. - P. 139-152.

6. Ho Yim-Chi. Music training improves verbal but not visual memory: cross-sectional and longitudinal explorations in children / Yim-Chi Ho, Mei-Chun Cheung, A. S. Chan // Neuropsychology. - 2003. - Vol. 17, № 3. - P. 439 .

7. Nering M. E. The effect of piano and music instruction on intelligence of monozygotic twins / M. E. Nering // Dissertation Abstracts International Section A: Humanities and Social Sciences. - 2002. - V. 63, №3-A. P. 812 .

8. Schellenberg E.G. Music lessons enhance IQ / E. G. Schellenberg // Psychological Science. - 2004. - V.15, № 8. - P. 511-514.

9. George E. M. Music training and working memory : an ERP study. / E. M. George, D. Coch // Neuropsychologia. - 2011. - V.49. - P. 1083-1094.

10. Lee Y. Effects of skill training on working memory capacity / Y. Lee, M. Lu, H. Ko // Learning and Instruction. - 2007. - V.17. - P. 336-344.

11. The effects of musical training on verbal memory / M. S. Franklin, K. Rattray, K. Sledge Moore [et al.] // Psychology of Music. - 2008. - P. 1-13.

12. Parbery-Clark A. Musician Enhancement for Speech-In-Noise / A. Parbery-Clark, E. C. Skoe, Lam, N. Kraus // Ear \& hearing. - 2009. - V. 30. - № 6. - P. 653-661.

13. Strait D. L. Musical experience shapes top-down auditory mechanisms: Evidence from masking and auditory attention performance / D. L. Strait, N. Kraus, A. Parbery-Clark, R. Ashley // Hearing Research. - 2001. V. 261. - P. 22-29.

14. Weissman D. The cerebral hemispheres cooperate to perform complex but not simple tasks / D. Weissman, M. Banich // Neuropsychology. - 2000. - V.14. - P. 41-59. 
15. Костандов Э. А. Фактор динамичности в функциональной асимметрии больших полушарий головного мозга / Э. А. Костандов // Физиология человека. - 1992. - Т. 18, № 3. - С. 17-24.

16. Baddeley A. D. The episodic buffer: a new component of working memory? / A. D. Baddeley // Trends in Cognitive Sciences. - 2000. - V. 4, №11. - P. 417-423.

17. Baddeley A. D. Working memory / A. D. Baddeley // Science. - 1992. - V. 225, № 5044. - P. 556-559.

18. Filimonova N. Features of processing of visual verbal and non-verbal information in human working memory / N. Filimonova, T. Kutsenko, M. Makarchuk // Physics of the alive. - 2006. - V.14, № 3. - P. 75-86.

19. Stroop J. R. Studies of interference in serial verbal reactions / J. R. Stroop // Journal of Experimental Psychology. - 1935. - Vol.18. - P. 643-662.

20. Куценко Т. В. Прояв прямого та зворотного ефекту Струпа при відповідях обома руками та кожною рукою окремо / Т. В. Куценко, Н. Б. Філімонова, С. С. Костенко // Вісник Черкаського університету. Серія «Біологічні науки. - 2009. - Т. 156. - С. 55-61.

21. Travis F. Moral development, executive functioning, peak experiences and brain patterns in professional and amateur classical musicians: Interpreted in light of a Unified Theory of Performance / F. Travis, H. S. Harung, Y. Lagrosen // Consciousness and Cognition. - 2011. - Vol. 20, № 4. - P. 1256-1264.

22. Carter C. S. Anterior cingulate cortex and conflict detection: an update of theory and data. / C. S. Carter, van V. Veen // Cognitive, Affective, \& Behavioral Neuroscience. - 2007. - Vol.7, № 4. - P. 367-379.

23. Wynn T. The expert Neandertal mind / T. Wynn, F. L. Coolidge // Journal of Human Evolution. - 2004. Vol. 46, № 4. - P. 467-487.

24. Sternberg S. High speed scanning in human memory / S. Sternberg // Science. - 1966. - V. 153. - P. $652-654$.

25. Sperling G. The information available in brief visual presentations / G. Sperling // Psychological Monographs: General and Applied. - 1960. - V.74, №11.

26. Куценко Т. Реакції «так» і «ні» правою й лівою рукою при дослідженні оперативної пам’яті на літери й цифри / Т. Куценко // Вісник Луганського національного університету імені Тараса Шевченка. 2010. - T. 21, № 208. - C. 60-66.

27. Derakhshan I. It Is All Quiet in the Minor Hemisphere: An Investigation into the Laterality of Consciousness, Attention and Vision in the Human Brain / I. Derakhshan // Biomedicine International. - 2010. - V.1. - P. 3-15.

28. Patston L. L. Attention in musicians is more bilateral than in non-musicians / L. L. Patston, S. L. Hogg, L. J. Tippett // Laterality. - 2007. - V.12, № 3. - P. 262-272.

29. The unusual symmetry of musicians: Musicians have equilateral interhemispheric transfer for visual information / L. M. Patston, I. J. Kirk, M. S. Rolfe [et al.] // Neuropsychologia. - 2007. - V. 45. - P. 2059-2065.

30. Okhrei A.G. Specificity of Auditory Cognitive Evoked Potentials in Musicians / A. G. Okhrei, T. V. Kutsenko, N. E. Makarchouk // Neurophysiology. -2012. - V.43, № 6. - P. 507-509.

Охрей Артем, Куценко Татьяна, Макарчук Николай. Моторная асимметрия в музыкантов и немузыкантов при оценке оперативной памяти и внимания. С целью выяснения асимметрии моторных реакций, которые возникают при осуществлении когнитивных задач, были использованы компьютеризированный прямой и обратный тесты Струпа, а также тесты для оценки работы оперативной памяти. Ответы в данных тестах предоставлялись обеими руками путем нажатия клавиш на клавиатуре компьютера. Обследуемыми были студенты Национальной музыкальной академии и их сверстники из Учебно-научного центра «Институт биологии» без предварительного музыкального или вокального опыта. Установлено, что музыканты и немузыканты имеют равную эффективность выполнения тестов, определенную по общему количеству допущенных ошибок, однако музыканты демонстрируют более симметричные моторные реакции, что может указывать на меньшую функциональную асимметрию и меньшую транскаллозальную задержку при осуществлении данных когнитивных задач.

Ключевые слова: моторная асимметрия, оперативная память, тест Струпа, музыканты, немузыканты.

Okhrei Artem, Kutsenko Tetyana, Makarchuk Mykola Musicians Have More Symmetrical Motor Reactions of Hands in Working Memory and Attention Tests. In order to estimate the asymmetry of motor reactions that occurs during the cognitive task, the direct and reversed computerized Stroop tests as well as tests for evaluating the working memory were carried out. Answers in these tests were given with both hands by pressing keys on the computer keyboard. Participants were students of the National Academy of Music and their peers from the Educational and Scientific Center «The Institute of Biology» without any previous musical or vocal experience. It was found that musicians and non-musicians have equally effective execution of tests by the total number of errors, but musicians showed more symmetrical motor reactions, which may indicate that musicians have lesser functional asymmetry and transcallosal delay during these cognitive tasks.

Key words: motor asymmetry, working memory, direct and reversed Stroop tests, musicians, non-musicians.

Стаття надійшла до редколегії 24.09.2016 р. 